\title{
Mucin associated Tn and sialosyl-Tn antigen expression in colorectal polyps
}

\author{
S H Itzkowitz, E J Bloom, T-S Lau, Y S Kim
}

\begin{abstract}
Sialosyl-Tn antigen and its immediate precursor, Tn antigen, are carbohydrate structures associated with the earliest steps of mucin O-linked glycosylation. Both antigens have been shown previously to be highly sensitive and specific markers of colorectal cancer. One hundred and three colorectal polyps (79 adenomatous; 24 hyperplastic) were examined for expression of Tn antigen using vicia villosa isolectin B4, and for sialosyl-Tn antigen by monoclonal antibody TKH2. Tn antigen was expressed by all of the polyps studied. SialosylTn, on the other hand was expressed weakly by a few cells in 7 of $24(29 \%)$ hyperplastic polyps. Among the adenomatous polyps, $56 \%$ expressed sialosyl-Tn and expression correlated with larger adenoma size, greater villous component, and more severe grades of dysplasia. In individuals with two or more synchronous adenomas, the level of sialosyl-Tn expression within an adenoma was associated with the severity of cytological atypia. All the adenomas that contained a focus of invasive carcinoma expressed sialosyl-Tn. These results indicate that colorectal polyps manifest incomplete glycosylation, exposing antigens in the innermost region of mucin oligosaccharides. In addition, the correlation of sialosyl-Tn antigen expression with the adenoma-carcinoma sequence may make this a useful marker for studying malignant progression in the colon.
\end{abstract}

For years it has been known that mucin elaborated by colon cancers differs qualitatively from that of the normal colon. ${ }^{12}$ However, the potential role of mucin in the biology of the colon cancer cell, and the stage in tumorigenesis at which these alterations occur, are only recently being elucidated. As part of a continuing analysis of mucin-associated carbohydrate antigen expression in colorectal tissues, we have been investigating carbohydrate antigens that represent some of the initial steps in mucin $\mathrm{O}$-linked glycosylation. The first step in mucin oligosaccharide synthesis involves the transfer of GalNAc to serine or threonine residues of the mucin polypeptide, forming the so called $\mathrm{Tn}$ antigen (GalNAc-O-ser/thr). ${ }^{3}$ This structure serves as a precursor for further glycosylation, such that if galactose is added to $\mathrm{Tn}$, the T antigen (Gal $\beta 1$, 3GalNAc-O-ser/thr) is formed, whereas if sialic acid is added, this creates the sialosyl-Tn antigen (Sia 2 , 6GalNAc-O-ser/thr). In a previous study we reported that each of these three antigens is rarely, if ever, expressed in normal colon, whereas expression occurs in the vast majority of colon cancers. ${ }^{+}$In another study that focused on $T$ antigen expression, we observed that $48 \%$ of hyperplastic polyps and $54 \%$ of adenomatous polyps reacted with monoclonal anti- $T$ antibody, and in the adenomas, $T$ antigen expression correlated with conventional histopathological parameters of malignant potential.'

With the recent availability of reagents that recognise $\mathrm{Tn}$ and sialosyl-Tn antigens, the present study aimed to elucidate the pattern of expression of these antigens in hyperplastic and adenomatous polyps and to determine whether expression might correlate with malignant potential in adenomas.

\section{Methods}

\section{TISSUE SPECIMENS}

A total of 103 polyps were obtained by endoscopic polypectomy. There were 24 hyperplastic polyps, each measuring less than $1 \mathrm{~cm}$ in diameter, and 79 adenomatous polyps with the following size distribution: $\leq 0.5 \mathrm{~cm} \quad(\mathrm{n}=12) ; 0.6-0.9 \mathrm{~cm}$ $(\mathrm{n}=35) ; 1.0-1.9 \mathrm{~cm} \quad(\mathrm{n}=24) ;$ and $\geq 2.0 \mathrm{~cm}$ $(n=8)$. Using haematoxylin and eosin stained slides, polyps were classified as to histological type and grade of dysplasia according to the criteria of Konishi and Morson. ${ }^{6}$ Adenomas containing carcinoma in situ were grouped with those containing severe dysplasia. Six of the adenomas had a focus of invasive adenocarcinoma. Synchronous polyps occurred in five patients: four patients had two adenomas, and one patient had four adenomas plus a hyperplastic polyp.

All polyps were fixed in formalin, embedded in paraffin and cut into $4 \mu \mathrm{m}$ serial sections for immunohistochemical staining.

\section{REAGENTS}

Monoclonal antibody TKH2 (IgG1) was raised against ovine submaxillary mucin and recognises sialosyl-Tn antigen. ${ }^{7}$ Hybridoma supernatant was a generous gift from Professor Sen-itiroh Hakomori, Biomembrane Institute, Seattle, WA. The B4 isolectin of vicia villosa seeds specifically agglutinates Tn-exposed erythrocytes. ${ }^{8}$ Biotinylated isolectin $\mathrm{B} 4$ of vicia villosa agglutinin was obtained from Sigma Chemical Co St Louis, MO. Biotinylated rabbit antimouse IgG+IgA+IgM, streptavidin-peroxidase conjugate, normal mouse IgG1, and normal rabbit serum were purchased from Zymed Laboratories, South San Francisco, CA.

\section{IMMUNOHISTOCHEMISTRY}

Immunoperoxidase histochemistry was performed using a streptavidin-peroxidase 
technique with all steps conducted at room temperature as previously described. ${ }^{+}$After deparaffinisation, slides were incubated with fresh $1 \%$ hydrogen peroxide in methanol for 10 minutes and then washed three times with buffered phosphate saline (PBS) $(0 \cdot 1 \mathrm{~mol} / 1$ phos-

TABLE I Expression of Tn and Sialosyl-Tn antigens in colonic tissues

\begin{tabular}{lllll}
\hline & $\begin{array}{l}\text { Normal } \\
\text { colon } \\
(n=22)\end{array}$ & $\begin{array}{l}\text { Hyperplastic } \\
\text { polyps } \\
(n=24)\end{array}$ & $\begin{array}{l}\text { Adenomatous } \\
\text { polyps } \\
(n=79)\end{array}$ & $\begin{array}{l}\text { Cancer } \\
(n=29)\end{array}$ \\
\hline $\mathrm{Tn}:$ & $3(14 \%)$ & $24(100 \%)$ & $79(100 \%)$ & $21(72 \%)$ \\
Sialosyl-Tn: & 0 & $7(29 \%)$ & $44(56 \%)$ & $28(96 \%)$
\end{tabular}

*Data on normal colon and colon cancer taken from reference 4.

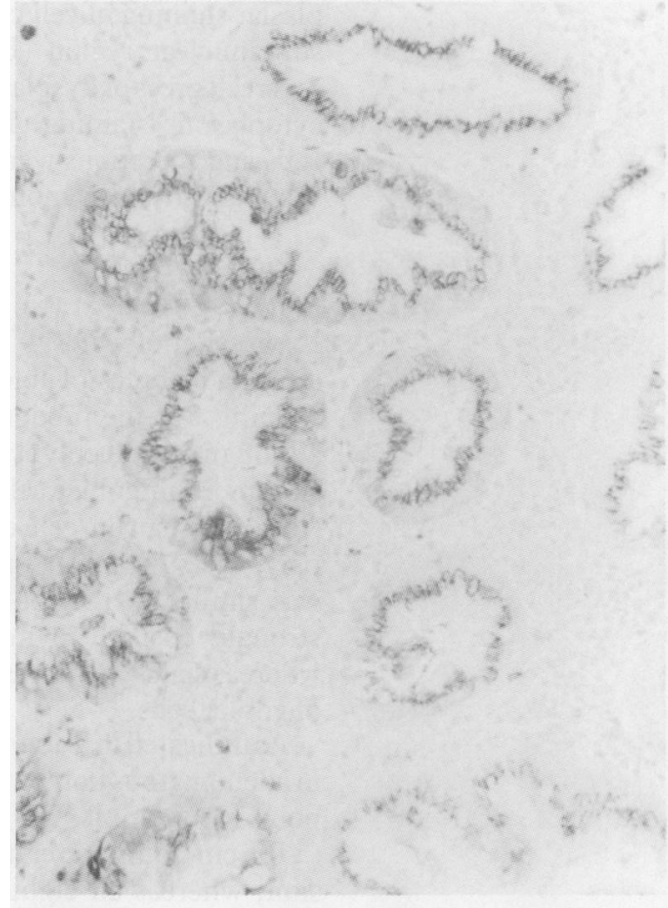

Fig $1 A$ phate, $0 \cdot 15 \mathrm{~mol} / \mathrm{l} \mathrm{NaCl}$, pH 7·4). Next, normal rabbit serum ( $5 \%$ in PBS) was added for 20 minutes and blotted off. Slides were then incubated with monoclonal antibody TKH2 (1:10 solution of hybridoma supernatant) or biotinylated vicia villosa agglutinin $(5 \mu \mathrm{g} / \mathrm{ml})$ for 90 minutes and then washed three times. The slides that received $\mathrm{TKH} 2$ were then treated with biotinylated rabbit anti-mouse $\operatorname{IgG}+\operatorname{Ig} \mathrm{A}+\operatorname{Ig} M$ $(10 \mu \mathrm{g} / \mathrm{ml}$ in PBS) for 20 minutes and washed three times. All sections then received streptavidin-peroxidase conjugate $(10 \mu \mathrm{g} / \mathrm{ml})$ for 30 minutes followed by three washes. Finally, slides were reacted with $3,3^{\prime}$ diaminobenzidine substrate for 10 minutes, rinsed with tap water, counterstained with methyl green, and mounted.

Negative controls consisted of substituting mouse IgG1 for monoclonal antibody TKH2 and preincubating biotinylated vicia villosa agglutinin with $0.2 \mathrm{~mol} / \mathrm{l} \mathrm{GalNAc} \mathrm{-} \mathrm{both} \mathrm{of} \mathrm{which}$ resulted in negative staining. Positive controls consisted of including an antigen-positive colon cancer slide with each assay. In addition, TKH2 often reacted with endothelial cells of mucosal blood vessels, which served as a useful internal positive control.

SCORING AND STATISTICAL ANALYSIS

Within each polyp, the percentage of antigen positive cells was estimated by examining each low power field $(10 \times$ objective $)$ containing adenomatous or hyperplastic colonic epithelium. To be scored as positive (as indicated in the Tables) a polyp had to exhibit antigen expression in at least $5 \%$ of cells. In adenomatous polyps, the relation of TKH2 reactivity (in cytoplasm or secretions) to adenoma size, histological type, and severity of dysplasia was analysed by logistic regression analysis. Slides were interpreted for antigen expression without knowledge of the final pathological diagnosis.
Figure 1: Expression of Tn and sialosyl-Tn antigens in hyperplastic polyps. (A) Tn is expressed in the

supranuclear cytoplasm of cells in all of the hyperplastic glands (original

magnification $\times 50$ ).

(B) Sialosyl-Tn is typically absent in the hyperplastic epithelial cells, but capillaries in the surrounding stroma are positive $(\times 50)$.

(C) A few hyperplastic

polyps expressed sialosyl-Tn antigen, but only a small percentage of cells were

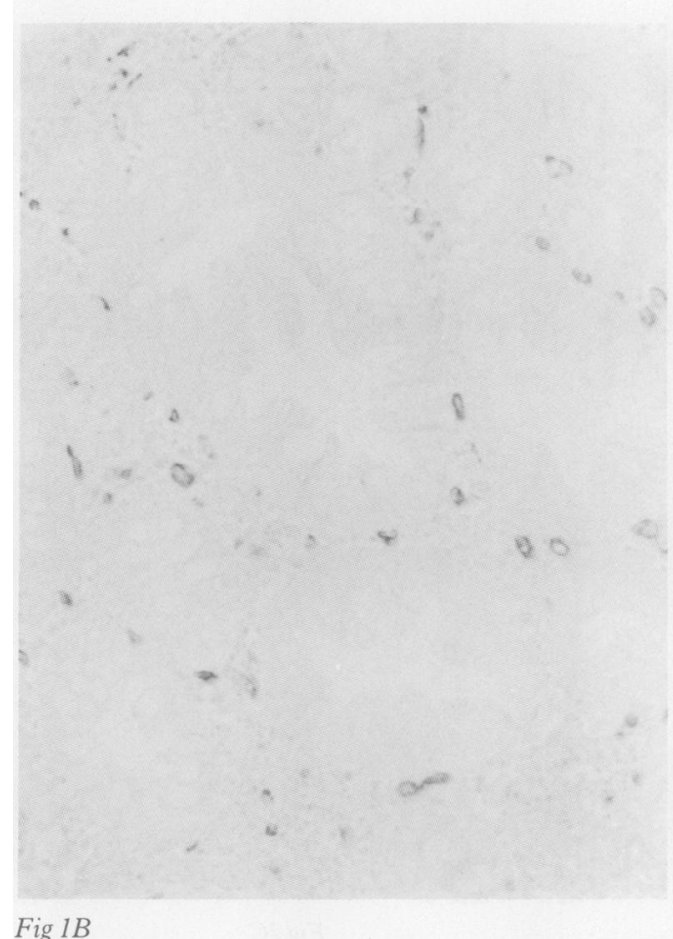




\section{Results}

HYPERPLASTIC POLYPS

\section{Tn antigen}

All the 24 hyperplastic polyps reacted with vicia villosa agglutinin (Table I). As indicated in Figure 1A, Tn antigen expression was found predominantly in the supranuclear cytoplasm (Golgi region). In addition, goblet cells in normal looking crypts adjacent to hyperplastic polyps were strongly positive.

\section{Sialosyl-Tn antigen}

In contrast to Tn antigen, sialosyl-Tn was found in only $7(29 \%)$ hyperplastic polyps (Table I).

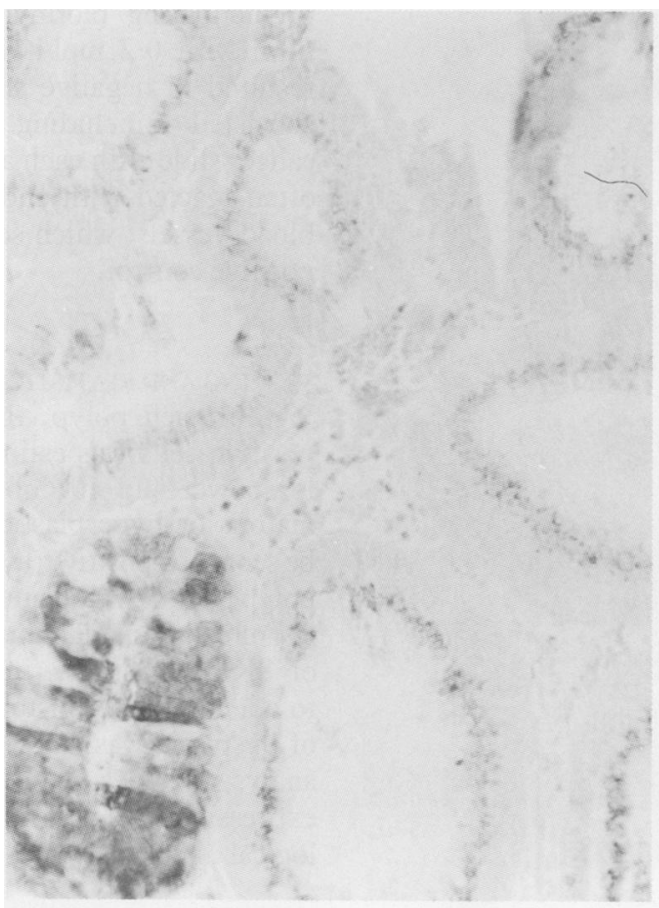

Fig $2 A$

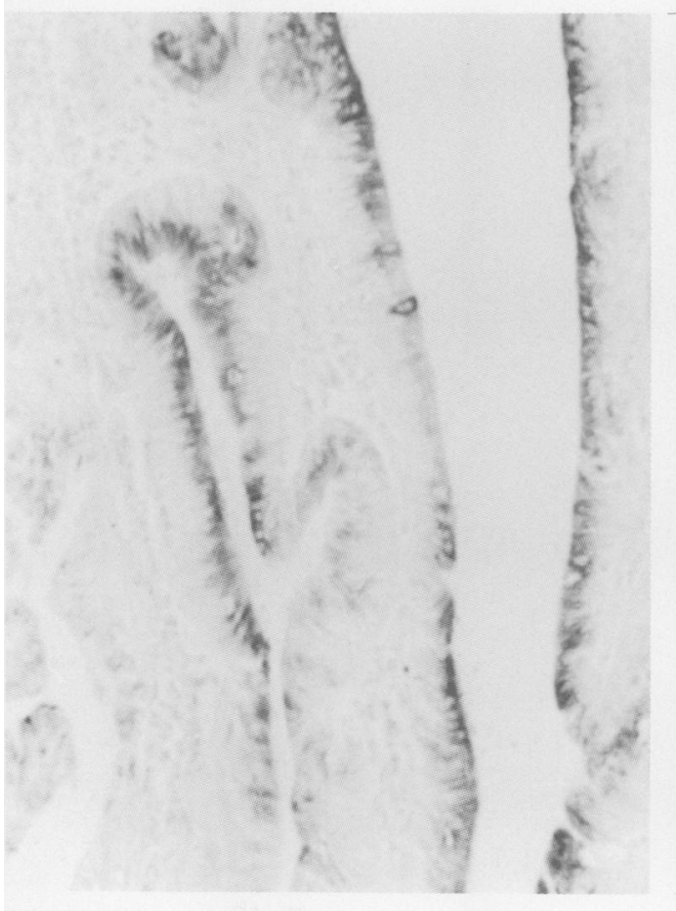

Most hyperplastic polyps showed complete absence of sialosyl-Tn expression in the epithelial cells (Fig 1B). The few hyperplastic polyps that expressed sialosyl-Tn exhibited antigen expression in a small subpopulation of cells (Fig 1C). Goblet cells were negative. Curiously, mucosal blood vessel endothelial cells reacted with monoclonal antibody TKH2 in almost every case - a phenomenon also noted previously in normal colonic mucosa.

\section{ADENOMATOUS POLYPS}

\section{Tn antigen}

All of the adenomatous polyps expressed Tn antigen (Table I). In adenomas with mild dysplasia, staining of cell cytoplasm occurred in the supranuclear region (Fig 2A), but with more severe degrees of dysplasia, cells exhibited diffuse cytoplasmic staining (Fig 2, B and C). Goblet cells and secretions were strongly positive in the vast majority of adenomas (Fig 2A).

\section{Sialosyl-Tn antigen}

Expression of sialosyl-Tn was noted in 44 of 79 $(56 \%)$ adenomas (Table I). Diffuse cytoplasmic staining was the predominant pattern (Fig 3A), although several polyps displayed antigen expression more in goblet cell vacuoles and secretions (Fig 3B) than in cell cytoplasm. For the most part, the subcellular distribution of sialosyl-Tn was similar to that of $\mathrm{Tn}$, except that $\mathrm{Tn}$ was strongly positive in most goblet cell vacuoles, whereas sialosyl-Tn was found in only a minority of goblet cells.

As indicated in Table II, sialosyl-Tn expression in adenomatous polyps was associated with larger polyp size. Of 12 diminutive adenomas $(\leq 0.5 \mathrm{~cm})$, only one exhibited sialosyl-Tn expression, whereas all eight adenomas over $2 \mathrm{~cm}$ in diameter were positive. Within each size cate-

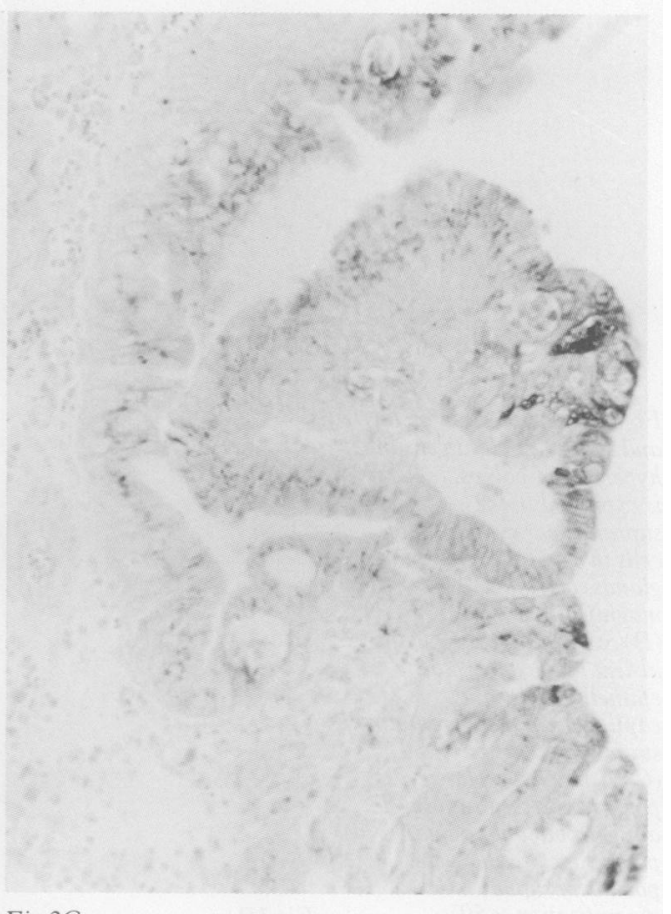

Figure 2: Tn antigen expression in adenomatous polyps. (A) Tubular adenoma with mild dysplasia. Tn antigen is expressed primarily in the supranuclear region of adenomatous cells. Goblet cells within the polyp are also positive (gland at lower left) original magnification $\times 50)$. (B) Villous adenoma with moderate dysplasia demonstrating diffuse cytoplasmic expression of $T n$ antigen (original magnification $\times 50$ ). (C) Area of severe dysplasia in a tubulovillous adenoma Supranuclear and diffuse cytoplasmic staining are present (original magnification $\times 50$ ) 
Figure 3: Sialosyl-Tn antigen expression in adenomatous polyps. (A) Villous adenoma with mild dysplasia

demonstrating intense in cell cytoplasm (original magnification $\times 50$ ). (B) Tubulovillous adenoma with severe dysplasia. Antigen expression is found (original magnification $\times 50)$. antigen expression diffusely in glandular secretions

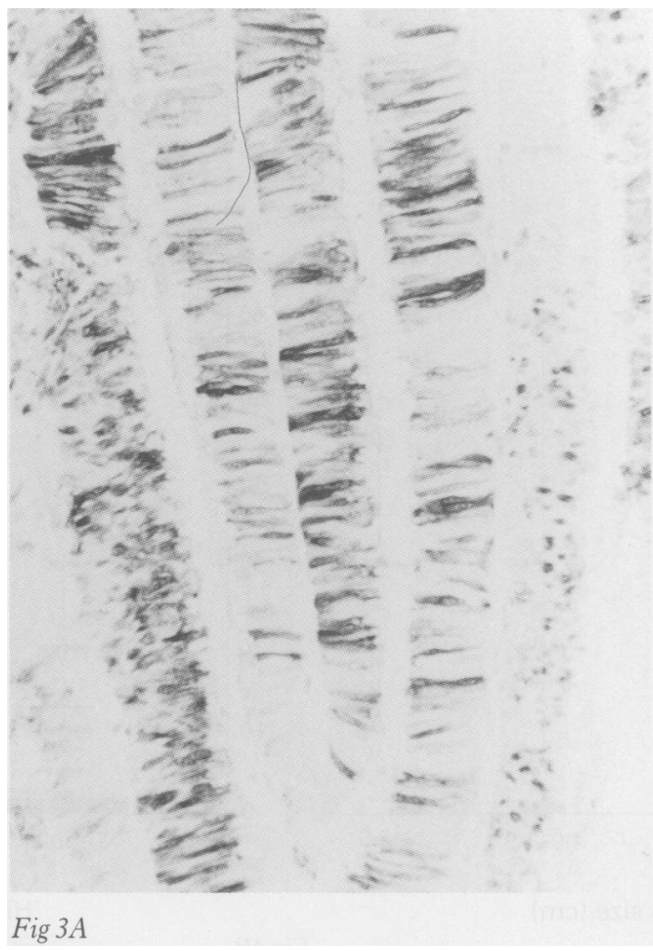

gory, and for the entire group of adenomas, the percentage of positive cases was greater in adenomas with more villous histology and more severe grades of dysplasia. Conversely, within each histological subset and each category of dysplasia, the percentage of positive cases showed a direct correlation with increasing polyp size.

All of the villous adenomas and all but one of the adenomatous polyps with severe dysplasia or carcinoma in situ expressed sialosyl-Tn (Table II). Table III shows that for a given histological type, the percentage of positive cases increases according to the severity of dysplasia within the adenoma.

Not all the cells in a given adenomatous polyps express sialosyl-Tn. Therefore, Figure 4 depicts the estimated percentage of positive cells in each adenomatous polyps according to polyp size (Fig 4A), histological type (Fig 4B), and severity of dysplasia (Fig 4C). Within each of these three histopathological categories, there was considerable overlap in values among polyps of different subsets. However, within each category, there was a statistically significant increase in the percentage of positive cells according to increasing malignant potential. When all three histopathological categories were considered simultaneously, TKH2 reactivity correlated best with

TABLE II Sialosyl-Tn expression in adenomatous polyps according to size

\begin{tabular}{|c|c|c|c|c|c|}
\hline & \multicolumn{4}{|l|}{ Size } & \multirow[b]{2}{*}{$\begin{array}{l}\text { Totals } \\
44 / 79(56 \%)\end{array}$} \\
\hline & $\begin{array}{l}\leq 0 \cdot 5 \mathrm{~cm} \\
1 / 12(8 \%)\end{array}$ & $\begin{array}{l}0.6-0.9 \mathrm{~cm} \\
18 / 35(46 \%)\end{array}$ & $\begin{array}{l}1 \cdot 0-1 \cdot 9 \mathrm{~cm} \\
17 / 24(71 \%)\end{array}$ & $\begin{array}{l}\geq 2.0 \mathrm{~cm} \\
8 / 8(100 \%)\end{array}$ & \\
\hline \multicolumn{6}{|l|}{ Histological type: } \\
\hline Tubular & $1 / 10(10 \%)$ & $12 / 29(41 \%)$ & $11 / 14(79 \%)$ & $1 / 1(100 \%)$ & $25 / 54(46 \%)$ \\
\hline Tubulovillous & $0 / 2(0 \%)$ & $3 / 3(100 \%)$ & $2 / 6(33 \%)$ & $5 / 5(100 \%)$ & $10 / 16(63 \%)$ \\
\hline Villous & - & $3 / 3(100 \%)$ & $4 / 4(100 \%)$ & $2 / 2(100 \%)$ & $9 / 9(100 \%)$ \\
\hline \multicolumn{6}{|l|}{ Degree of dysplasia: } \\
\hline Mild & $1 / 11(9 \%)$ & $8 / 24(33 \%)$ & $8 / 14(57 \%)$ & - & $17 / 49(35 \%)$ \\
\hline Moderate & $0 / 1(0 \%)$ & $5 / 5(100 \%)$ & $2 / 3(67 \%)$ & $2 / 2(100 \%)$ & $9 / 11(82 \%)$ \\
\hline Severe (cis) & - & $5 / 6(83 \%)$ & $7 / 7(100 \%)$ & $6 / 6(100 \%)$ & $18 / 19(95 \%)$ \\
\hline
\end{tabular}

cis $=$ carcinoma in situ.

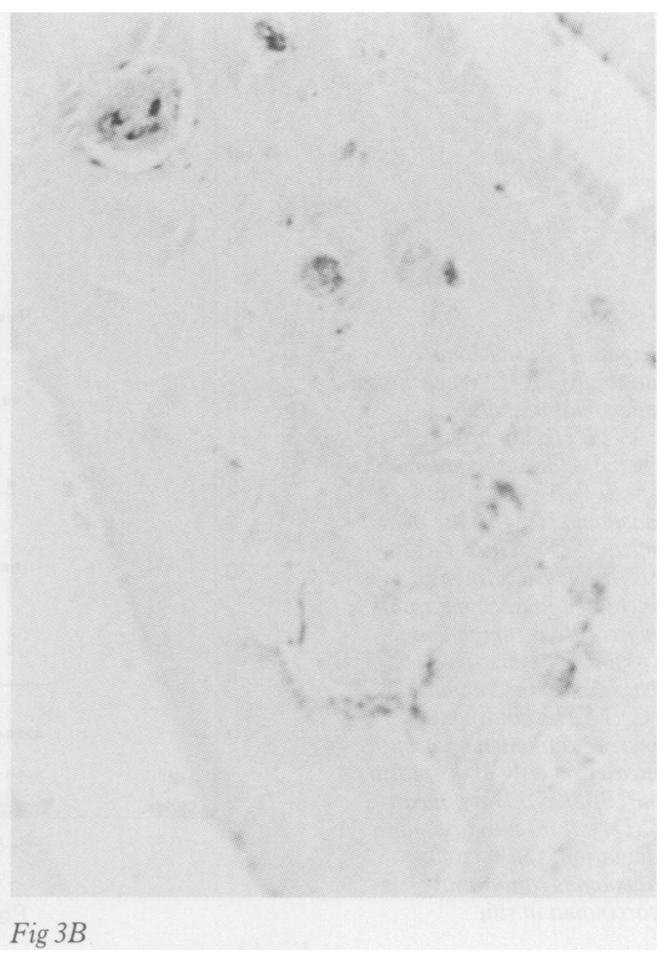

dysplasia $(\mathrm{p}<0.005)$ and adenoma size $(\mathrm{p}<0.05)$, but not with histological type.

All six adenomas containing a focus of invasive carcinoma were sialosyl-Tn positive. However, the invading cancer cells were not always antigen positive.

The staining pattern of monoclonal antibody TKH2 in patients with synchronous polyps is shown in Table IV. This analysis demonstrated that even within a particular individual, the staining pattern of multiple polyps was not alike. In this group, it was the degree of dysplasia and not adenoma size or histological type that seemed to determine the level of sialosyl-Tn expression.

\section{Discussion}

Many studies have examined colorectal polyps for the expression of mucin species in general, using conventional mucin histochemical techniques, ${ }^{9}$ or particular carbohydrate structures on mucins, using monoclonal antibody or lectin immunohistochemistry. ${ }^{10-15}$ Generally, however, these studies have not focused on the expression of specific carbohydrate antigens in the innermost 'core' region of mucin O-linked oligosaccharides. In the present study two such antigens, $\mathrm{Tn}$ and sialosyl-Tn, were simultaneously examined in colorectal polyps because our previous study found these antigens to be highly sensitive and specific markers of colorectal cancer. ${ }^{+}$

TABLE III Sialosyl-Tn expression in adenomas of different histological types

\begin{tabular}{llll}
\hline & \multicolumn{4}{l}{ Degree of dysplasia } \\
\cline { 2 - 4 } Histological type & Mild & Moderate & Severe (cis) \\
\hline Tubular $(\mathrm{n}=54)$ & $16 / 44(36 \%)$ & $4 / 4(100 \%)$ & $5 / 6(83 \%)$ \\
Tubulovillous $(\mathrm{n}=16)$ & $1 / 5(20 \%)$ & $2 / 4(50 \%)$ & $7 / 7(100 \%)$ \\
Villous $(\mathrm{n}=9)$ & - & $3 / 3(100 \%)$ & $6 / 6(100 \%)$
\end{tabular}

cis $=$ carcinoma in situ. 
Figure 4: Monoclonal antibody TKH2 reactivity in adenomatous.polyps. (A) $T K H 2$ binding is increased in larger adenomas adenoma size (in $\mathrm{cm}$ ). Bars: mean $(S D)$ values. increased in adenomas with more villous component $(p<0 \cdot 01)$. Bars: mean $(S D)$ values standard deviation. increased in adenomas with greater severity of dysplasia $(S D)$ values standard deviation. Open circles: adenomas containing carcinoma in situ. $(p<0.005)$. Abscissa:

(B) $T K H 2$ binding is (C) $T K H 2$ binding is $(p<0 \cdot 0005)$. Bars: mean

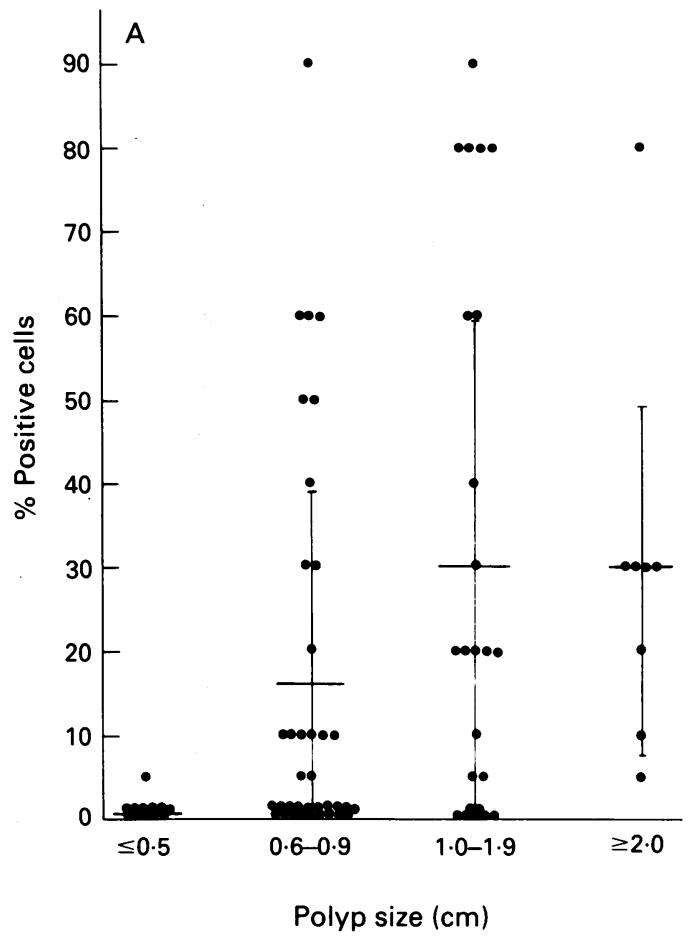

Fig $4 A$

Tn antigen was expressed by all hyperplastic and adenomatous polyps. Since hyperplastic polyps are believed to have no malignant potential, ${ }^{16}$ this finding would suggest that $\mathrm{Tn}$ antigen is not a good discriminant of malignant potential in polyps. However, it may be noteworthy that in adenomas, the cytological pattern of Tn antigen changed from a predominantly supranuclear (presumably Golgi) location to a diffuse intracytoplasmic pattern in accordance with increasing severity of dysplasia. Furthermore, the expression of $\mathrm{Tn}$ antigen in goblet cell vacuoles immediately adjacent to adenomatous and hyperplastic polyps is a pattern reminiscent of mucosa immediately adjacent to carcinomas but which was not seen in normal mucosa. ${ }^{+}$Other investigators have also noted that vicia villosa agglutinin reacted with all hyperplastic and adenomatous polyps, with staining localised primarily to the supranuclear cytoplasm. ${ }^{17}$ However, in that study, vicia villosa agglutinin reac-

TABLE IV Sialosyl-Tn expression in multiple polyps from the same individual

\begin{tabular}{|c|c|c|c|c|c|}
\hline & Size $(\mathrm{cm})$ & $\begin{array}{l}\text { Histological } \\
\text { type }\end{array}$ & $\begin{array}{l}\text { Degree of } \\
\text { dysplasia }\end{array}$ & Cytoplasm & Secretions \\
\hline $\begin{array}{l}\text { Patient A } \\
\text { Adenoma 1 } \\
\text { Adenoma } 2\end{array}$ & $\begin{array}{l}0.9 \\
1 \cdot 1\end{array}$ & $\begin{array}{l}\mathrm{T} \\
\mathrm{V}\end{array}$ & $\begin{array}{l}\text { Mild } \\
\text { Severe }\end{array}$ & $\bar{t}++(80)^{\star}$ & $\overline{+}(5)$ \\
\hline $\begin{array}{l}\text { Patient B } \\
\text { Adenoma } 1 \\
\text { Adenoma } 2\end{array}$ & $\begin{array}{l}1.0 \\
0.9\end{array}$ & $\begin{array}{l}T-V \\
T-V\end{array}$ & $\begin{array}{l}\text { Mild } \\
\text { cis }\end{array}$ & $\bar{t}++(50)$ & - \\
\hline $\begin{array}{l}\text { Patient C } \\
\text { Adenoma } 1 \\
\text { Adenoma } 2\end{array}$ & $\begin{array}{l}0 \cdot 5 \\
2 \cdot 0\end{array}$ & $\begin{array}{l}T-V \\
V\end{array}$ & $\begin{array}{l}\text { Moderate } \\
\text { Severe }\end{array}$ & $\bar{t}++(80)$ & $\begin{array}{l}- \\
+(10)\end{array}$ \\
\hline $\begin{array}{l}\text { Patient D } \\
\text { Adenoma } 1 \\
\text { Adenoma } 2\end{array}$ & $\begin{array}{l}0.7 \\
0.7\end{array}$ & $\begin{array}{l}T \\
T\end{array}$ & $\begin{array}{l}\text { cis } \\
\text { Severe }\end{array}$ & $\begin{array}{l}+(40) \\
-\end{array}$ & - \\
\hline $\begin{array}{l}\text { Patient E } \\
\text { Adenoma } 1 \\
\text { Adenoma } 2 \\
\text { Adenoma 3 } \\
\text { Adenoma } 4 \\
\text { Hyperplastic }\end{array}$ & $\begin{array}{l}0.8 \\
1.0 \\
0.8 \\
1 \cdot 1 \\
0.9\end{array}$ & $\begin{array}{l}T \\
T \\
T \\
T \\
\text { NA }\end{array}$ & $\begin{array}{l}\text { Mild } \\
\text { Mild } \\
\text { Mild } \\
\text { Mild } \\
\text { NA }\end{array}$ & $\begin{array}{l}- \\
- \\
- \\
- \\
-\end{array}$ & $\begin{array}{l}++(10) \\
+(5) \\
+(20) \\
+(10) \\
-\end{array}$ \\
\hline
\end{tabular}

$\mathrm{T}=$ tubular; $\mathrm{T}-\mathrm{V}=$ tubulovillous; $\mathrm{V}=$ villous

^Staining intensity: -absent; + weak; ++ moderate +++ strong.

Numbers in parenthesis: estimated percentage of positive cells.

$\mathrm{NA}=$ not applicable.

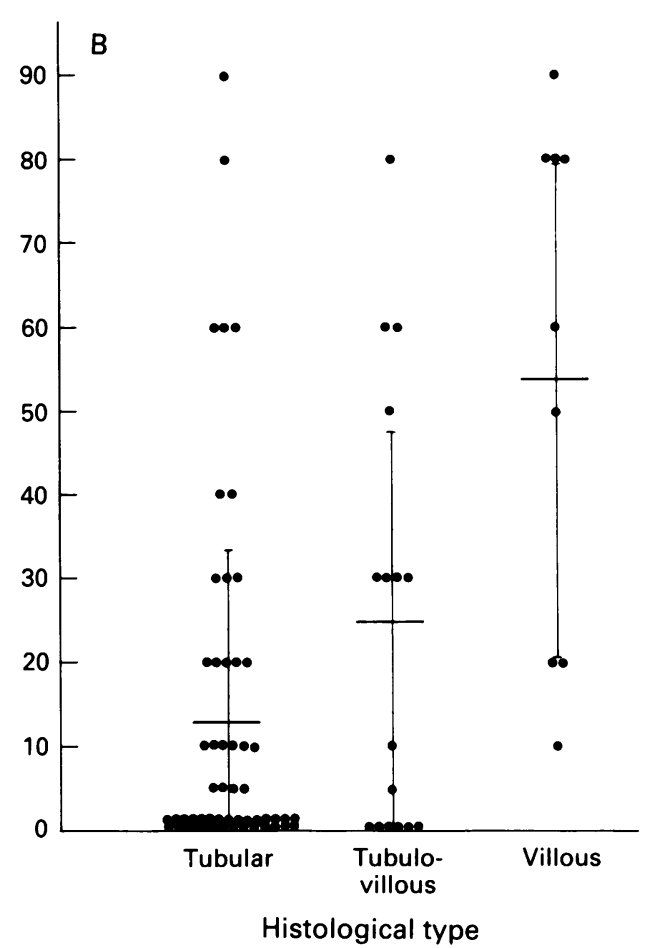

Fig $4 B$

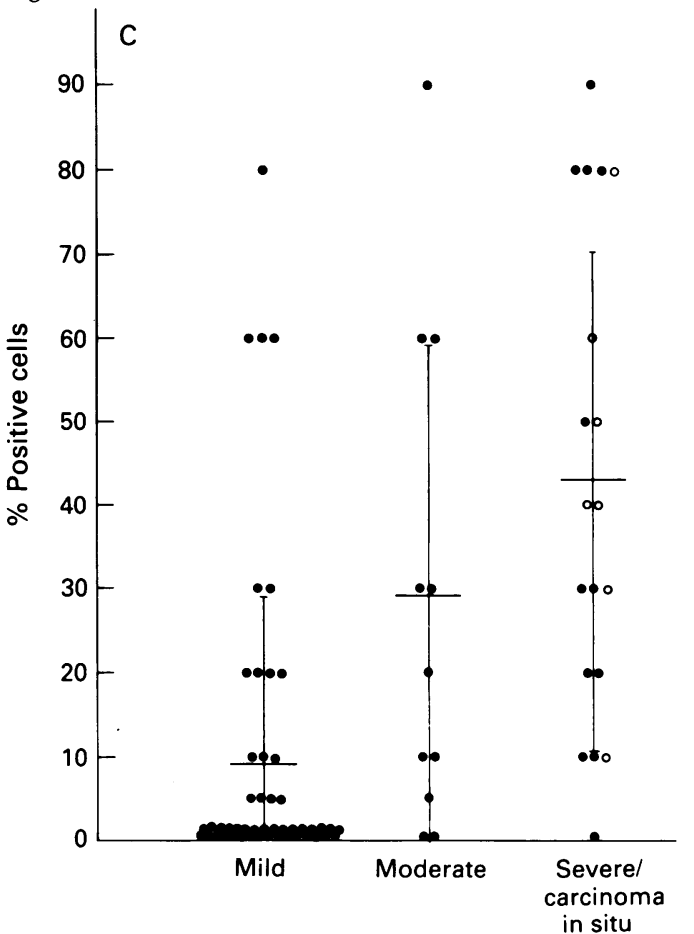

Fig 4 C

Degree of dysplasia

tivity was diminished in adenomas with carcinoma in situ and frank carcinomas.

Sialosyl-Tn, unlike $\mathrm{Tn}$, did discriminate between hyperplastic and adenomatous polyps. Only a few hyperplastic polyps reacted with monoclonal antibody $\mathrm{TKH} 2$, and those that were positive usually exhibited weak staining intensity in only a few cells. Adenomatous polyps, on the other hand, expressed sialosyl-Tn in $56 \%$ of cases, and those that were positive were the larger, more villous, and more dysplastic adenomas. In fact, all adenomas over $2 \mathrm{~cm}$ in diameter, all villous adenomas, and all but one adenoma showing severe dysplasia or carcinoma in situ expressed sialosyl-Tn antigen. Thus, sialosyl-Tn antigen expression by adenomas 
seems to be associated with their malignant potential. This is supported by the finding that in individuals with more than one adenoma, sialosyl-Tn expression correlated with the severity of cellular dysplasia. We have observed that sialosyl-Tn expression by colon cancer tissues was associated with a poor prognosis whereas individuals with sialosyl-Tn negative tumours had overall and disease free five year survival rates $100 \%$ and $94 \%$, respectively..$^{18}$ In addition, sialosyl-Tn expression is apparently increased in metastatic colon cancer cells. ${ }^{19}$ Thus, expression of sialosyl-Tn antigen seems to be a marker of malignant progression in the colon.

To our knowledge, no study, has examined sialosyl-Tn expression in colorectal polyps with monoclonal antibody TKH2. However, monoclonal antibody B72.3 has been used to stain colorectal polyps in a few studies. ${ }^{20-22}$ In one study, only rare $(<10 \%$ of cells) B72.3 reactivity was noted in $1 / 20$ adenomas from patients with concomitant colon cancers, and in 5/18 adenomas from adenoma bearing patients. ${ }^{20}$ However, in that study no villous adenomas were examined, and data concerning adenoma size and degree of dysplasia were not provided. Wolf et al reported monoclonal antibody $\mathrm{B} 72.3$ reactivity in $0 / 20$ hyperplastic polyps and 13/81 (16\%) adenomatous polyps, with staining associated only with tubulovillous or villous adenomas manifesting moderate or severe dysplasia. ${ }^{21}$ In contrast, Listrom et al found that 20/20 (100\%) adenomatous polyps and $43 / 46$ (96\%) hyperplastic polyps reacted with monoclonal antibody B72.3. ${ }^{22}$ The discrepancies between the studies that have used B72.3 are difficut to explain, but could relate to differences in technique. In addition, although monoclonal antibody B72.3 has been shown to react with sialosyl-Tn antigen, ${ }^{723}$ recent data from the First International Workshop on Carcinoma-Associated Mucins (unpublished observations) indicates that this antibody also crossreacts with Tn antigen, whereas TKH2 used in the present study is specific for sialosyl-Tn.

Biochemical structural analysis of oligosaccharides on normal colonic mucin indicates that $\mathrm{Tn}$ and sialosyl-T $\mathrm{n}$ antigens are frequently found as internal structures adjacent to the apomucin polypeptide..$^{2+25}$ Typically, however, these normal oligosaccharides are several sugars in length, which presumably prevents the binding of lectins or monoclonal antibodies to the innermost structures. This might explain the lack of vicia villosa agglutinin or TKH2 binding to normal colonocytes. The present study, showing that vicia villosa agglutinin binds to hyperplastic and adenomatous polyps suggests that these lesions manifest incomplete glycosylation ${ }^{26}$ thereby exposing the $\mathrm{T} n$ antigen. The expression of sialosyl-Tn in colonic polyps is also consistent with this concept. However, sialosyl-Tn antigen, but not $\mathrm{Tn}$ antigen, was selectively expressed by polyps with greater malignant potential. This indicates that during malignant transformation, although incomplete glycosylation is common, certain glycosylation pathways are preferred. Supported by PHS Grants ROI CA 52491 (SHI), and CA 47551
(YSK) from the National Cancer Institute, the Medical Research
Service and a Medical Investigator Award from the Veterans Administration (YSK), and awards from the Aaron Diamond Foundation and The Chemotherapy Foundation (SHI)

An abstract of this work has been published in Gastroenterology 990; 98: A288.

The authors gratefully acknowledge Annabelle Friera and Pat Martinez for technical assistance, and Marguerite Pizzati for manuscript preparation.

1 Gold DV, Miller F. Comparison of human colonic mucoprotein antigen from normal and neoplastic mucosa. Cancer Res 1978; 38: 3204-11.

2 Kim YS, Isaacs R. Glycoprotein metabolism in inflammatory and neoplastic diseases of the human colon. Cancer Res 1975 35: 2092-7.

3 Schachter H, Williams D. Biosynthesis of mucus glycoproteins. In: Chantler EN, Elder JB, Elstein M, eds. Mucus in health and disease II. New York: Plenum Publishing, 1982: 3-28.

4 Itzkowitz SH, Yuan M, Montgomery CK, Kjeldsen T, Takahashi HK, Bigbee WL, et al. Expression of Tn, sialosy $\mathrm{Tn}$, and $\mathrm{T}$ antigens in human colon cancer. Cancer Res 1989; 49: $197-204$.

5 Yuan M, Itzkowitz SH, Boland CR, Kim YD, Tomita JT, Palekar A, et al. Comparison of T-antigen expression in normal, premalignant and malignant human colonic tissues using lectin and antibody immunohistochemistry. Cancer Res 1986; 46: 4841-7.

6 Konishi F, Morson BC. Pathology of colorectal adenomas: a colonoscopic survey. $\mathcal{F}$ Clin Pathol 1982; 35: 830-41.

7 Kjeldsen T, Clausen $H$, Hirohashi S, Ogawa T, Iijima $H$ Hakomori S. Preparation and characterization of monoclonal antibodies directed to the tumor-associated O-linked sialosyl-2 $\rightarrow \quad 6 \alpha-\mathrm{N}$-acetylgalactosaminyl (sialosyl-Tn) sialosyl-2 $\rightarrow \quad 6 \alpha-\mathrm{N}$-acetylgalactosaminyl

Tollefsen SE, Kornfeld R. The $B_{4}$ lectin from Vicia villosa seeds interacts with $N$-acetylgalactosamine residues $\alpha$-linked to serine or threonine residues in cell surface glycoproteins f Biol Chem 1983; 258: 5172-6.

9 Griffioen G, Bosman FT, Verspaget HW, DeBruin PAF, Biemond I, Lamers CBHW. Mucin profiles and potential for malignancy of human colorectal adenomatous polyps. Cancer 1989; 63: 1587-91.

10 Boland CR, Montgomery CK, Kim YS. A cancer-associated mucin alteration in benign colonic polyps. Gastroenterology 1982; 82: 664-72.

11 Cooper HS, Reuter VE. Peanut lectin-binding sites in polyps of the colon and rectum: adenomas, hyperplastic polyps, and
adenomas with in situ carcinoma. Lab Invest 1983; 49: 655-61.

12 Rhodes JM, Black RR, Savage A. Glycoprotein abnormalities in colonic carcinomata, adenomata, and hyperplastic polyps shown by lectin peroxidase histochemistry. $\mathcal{F}$ Clin Pathol 1986; 39: $1331-4$.

13 Itzkowitz SH, Yuan M, Ferrell LD, Palekar A, Kim YS Cancer-associated alterations of blood group antigen expression in human colorectal polyps. Cancer Res 1986; 46: 5976-84.

14 Kim YS, Yuan M, Itzkowitz SH, Sun Q, Palekar A, Trump $\mathrm{BF}$, et al. Expression of $\mathrm{Le}^{y}$ and extended $\mathrm{Le}^{y}$ blood grouprelated antigens in human malignant, premalignant and nonmalignant colonic tissues. Cancer Res 1986; 46: 5985-92.

15 Yuan M, Itzkowitz SH, Ferrell L, Fukushi Y, Palekar A, Hakomori S, et al. Expression of $\mathrm{Le}^{\mathrm{x}}$ and sialylated $\mathrm{Le}^{\mathrm{x}}$ related antigens in human colorectal polyps. 7 Natl Cancer Inst 1987; 78: 479-88.

16 Fenoglio-Preiser CM. Hyperplastic polyps, adenomatous polyps, and mixed hyperplastic adenomatous polyps of the polyps, and mixed hyperplastic adenomatous polyps of the colon. In: Steele Jr G, Burt RW, Winawer SJ, Karr JP, eds. Basic and clinical perspectives of colorecta

17 Kellokumpu I, Karhi K, Andersson LC. Lectin-binding sites in normal, hyperplastic, adenomatous and carcinomatous human colorectal mucosa. Acta Pathol Microbiol Immuno Scand [A] 1986; 94: 271-80.

18 Itzkowitz SH, Bloom EJ, Kokal WA, Modin G, Hakomori S Kim YS. Sialosyl-Tn: a novel mucin antigen associated with prognosis in colorectal cancer patients. Cancer 1990; 66: $1960-6$.

19 Bresalier RS, Ho SB, Kim YS. Alterations in mucin type glycoproteins in human colorectal cancer metastases. Gastroenterology 1990; 98: A274.

20 Stramignoni D, Bowen R, Atkinson BF, Schlom J, Differential reactivity of monoclonal antibodies with human colon reactivity of monoclonal antibodies with human colon 543-52.

21 Wolf BC, D'Emilia JC, Salem RR, DeCoste D, Sears HF, Gottlieb LS, et al. Detection of tumor-associated glycoprotein antigen (TAG-72) in premalignant lesions of the colon. $\mathcal{F}$ Natl Cancer Inst 1989; 81: 1913-7.

22 Listrom MB, Little JV, McKinley M, Fenoglio-Preiser CM. Immunoreactivity of tumor-associated glycoprotein (TAG72 ) in normal, hyperplastic, and neoplastic colon. Hum Pathol 1989; 20: 994-1000.

23 Gold DV, Mattes MJ. Monoclonal antibody B72.3 reacts with a core region structure of 0 -linked carbohydrates. Tumour Biol 1988; 9: 137-44.

24 Podolsky DK. Oligosaccharide structures of human colonic mucin. ₹ Biol Chem 1985; 260: 8262-71.

25 Podolsky DK. Oligosaccharide structures of isolated human colonic mucin species. F Biol Chem 1985; 260: 15510-5.

26 Hakomori S. Aberrant glycosylation in cancer cell membranes as focused on glycolipids: overview and perspectives. Cancer Res $1985 ; 45: 2405-14$. 